Escherichia coli isolates in South Africa. Antimicrob Agents Chemother. 2016;60:4394-7. http://dx.doi.org/10.1128/ AAC.00444-16

7. Nordmann P, Poirel L. Plasmid-mediated colistin resistance: an additional antibiotic resistance menace. Clin Microbiol Infect. 2016;22:398-400. http://dx.doi.org/10.1016/j.cmi.2016.03.009

8. Hasman H, Hammerum AM, Hansen F, Hendriksen RS, Olesen B, Agersø $\mathrm{Y}$, et al. Detection of $m c r-1$ encoding plasmid-mediated colistin-resistant Escherichia coli isolates from human bloodstream infection and imported chicken meat, Denmark 2015.

Euro Surveill. 2015;20:30085. http://dx.doi.org/10.2807/ 1560-7917.ES.2015.20.49.30085

9. Kuo SC, Huang WC, Wang HY, Shiau YR, Cheng MF, Lauderdale TL. Colistin resistance gene mcr-1 in Escherichia coli isolates from humans and retail meats, Taiwan. J Antimicrob Chemother. 2016;71:2327-9. http://dx.doi.org/10.1093/jac/dkw122

10. Campos J, Cristino L, Peixe L, Antunes P. MCR-1 in multidrugresistant and copper-tolerant clinically relevant Salmonella 1,4,[5],12:i:- and S. Rissen clones in Portugal, 2011 to 2015. Euro Surveill. 2016;21:30270. http://dx.doi.org/10.2807/ 1560-7917.ES.2016.21.26.30270

Address for correspondence: Marta Tacão, Biology Department, University of Aveiro, Campus Universitário Santiago, 3810-193 Aveiro, Portugal; email: martat@ua.pt

\section{Outcomes for 2 Children after Peripartum Acquisition of Zika Virus Infection, French Polynesia, 2013-2014}

\section{Marianne Besnard, Timothée Dub, Patrick Gérardin}

Author affiliations: Centre Hospitalier de Polynésie Française, Pirae, Tahiti (M. Besnard); Institut Pasteur, Paris, France

(T. Dub); Centre Hospitalier Universitaire, Saint Pierre, Réunion (P. Gérardin)

DOI: https://doi.org/10.3201/eid2308.170198

Congenital Zika virus infection is associated with severe brain anomalies and impaired function. To determine outcomes, we followed 2 affected children for $\approx 30$ months. For 1 who was symptomatic at birth, transient hepatitis developed. However, neurodevelopment for both children was age appropriate.

$\mathrm{Z}$ ika virus, a flavivirus, is a teratogenic and neurotropic infectious pathogen (1). Zika virus infection during pregnancy causes congenital microcephaly and severe brain anomalies (2). In the newly recognized congenital Zika syndrome, infection is also associated with partially collapsed skull, retinal damage, congenital contractures, early-onset hypertonia, and signs of extrapyramidal involvement; irrespective of a clear pathomechanism, infection is also associated with intrauterine growth restriction and low birth weight (1). Developmental outcomes for children born with congenital Zika virus infection have been reported for infants with severe brain anomalies as consequences of early prenatal exposure $(3,4)$ and include postnatal slowing of head circumference growth and impaired function.

After the first large-scale Zika outbreak in French Polynesia, October 2013-April 2014 (5), 2 cases of peripartum Zika virus infection in full-term neonates were reported (6). We report the follow-up and developmental outcomes through $\approx 30$ months of age for these 2 children. We evaluated cognition by using the Child Development Assessment Scale (CDAS), a screening test suitable for children 0-5 years of age (online Technical Appendix, https:// wwwnc.cdc.gov/EID/article/23/8/17-0198-Techapp1.pdf).

Case-patient 1 was born at 38 weeks' gestation; his weight, size, and neurologic status were within reference ranges for gestational age. His mother manifested a rash, suggestive of Zika virus infection, on day 2 after delivery. Reverse transcription PCRs for Zika virus were positive in blood and saliva from the mother (day 2) and neonate (day 3 ) and in breast milk on day 2 . The neonate was breastfed for 2 months. He remained asymptomatic, and his neurologic development followed a typical course. At 32 months of age, CDAS scores indicated a need to monitor motor development but overall did not indicate neurocognitive problems.

Case-patient 2 was also born at 38 weeks' gestation but was small for gestational age (weight $1,925 \mathrm{~g}$; height 42 $\mathrm{cm}$; head circumference $32 \mathrm{~cm}$ ). Signs of Zika virus infection (rash) appeared in the mother on day 3 and in the neonate on day 4. Reverse transcription PCRs for Zika virus of blood and urine were positive for the mother (day 1) and the neonate (days 4 and 7) and in breast milk on day 8. On day 2, laboratory testing of blood from the neonate indicated thrombocytopenia $\left(65.0 \times 10^{9}\right.$ thrombocytes/L), leukopenia $\left(4.6 \times 10^{9}\right.$ cells $\left./ \mathrm{L}\right)$, cytolysis, and cholestasis (Table); the cholestasis resolved 4 months later. Ultrasonograms of the liver were unremarkable, and albumin levels and hemostasis remained within reference ranges. Breastfeeding was maintained for 6 months. At 30 months of age, the child's growth remained within -2 SD for weight $(10,725 \mathrm{~g})$ and head circumference $(47 \mathrm{~cm})$ and $-1.5 \mathrm{SD}$ for height $(86$ $\mathrm{cm})$. CDAS scores indicated no developmental neurocognitive problems.

Follow-up of these 2 case-patients showed that peripartum Zika virus infection, the exposure situation of mother- 
Table. Follow-up of liver function test results associated with perinatal Zika virus infection in case-patient 2, French Polynesia, 2014*

\begin{tabular}{|c|c|c|c|c|}
\hline Date (postnatal day) & AST, U/L† & ALT, U/L $\ddagger$ & GGT, U/L§ & Bilirubin, total/conjugate, $\mathrm{mg} / \mathrm{LI}$ \\
\hline Feb $4(2)$ & 84 & 11 & 201 & 158 \\
\hline Feb $6(4)$ & 38 & 12 & 297 & 145 \\
\hline Feb $10(8)$ & 52 & 18 & 457 & $128 / 21$ \\
\hline Apr 8 (57) & 348 & 150 & 281 & $66 / 54$ \\
\hline Apr $16(65)$ & 239 & 139 & 312 & $50 / 42$ \\
\hline Apr 30 (79) & 117 & 86 & 239 & 10 \\
\hline May 13 (92) & 119 & 104 & 164 & 8 \\
\hline Jun 17 (120) & 57 & 51 & 40 & 2 \\
\hline Oct $25(250)$ & 38 & 47 & 27 & 2 \\
\hline
\end{tabular}

*Boldface indicates values out of reference range. ALT, alanine aminotransferase; AST, aspartate aminotransferase; GGT, gamma-glutamyl transferase. †Reference range $15-40 \mathrm{U} / \mathrm{L}$.

$\ddagger$ Reference range $10-40 \mathrm{U} / \mathrm{L}$

§Reference range $2-34 \mathrm{U} / \mathrm{L}$.

IReference range $<14 /<3 \mathrm{mg} / \mathrm{L}$.

to-child transmission of Zika virus during gestation (when the mother is viremic during childbirth), was associated with neither marked illness at birth nor neurodevelopmental deficits by 30 months of age. However, assessment of lateonset cognitive or sensory deficits requires longer follow-up. Transmission is assumed unlikely to occur through breastfeeding; Zika virus isolated from milk is not replicative (6). For the 2 case-patients reported here, transmission by contact with the vaginal secretions seems unlikely; viral shedding in these secretions is scarce and weak (7).

Prolonged subclinical hepatitis in case-patient 2, such as that observed with congenital cytomegalovirus infection, resolved after 4 months. To the best of our knowledge, liver pathogenesis in living neonates with Zika virus infection has not been reported but is common with other arboviral (e.g., dengue virus) infections. This milder pattern of peripartum Zika virus infection differs from the usually severe neonatal dengue virus infection (severe thrombocytopenia) and peripartum chikungunya virus infection (postnatal encephalopathy).

Our findings, along with findings of mild brain lesions (e.g., subependymal cysts and lenticulo-striate vasculitis) after late intrauterine exposure to Zika virus (8), need to be replicated on larger populations before it can be suggested that placental and blood-brain barriers may be effective late in gestation, after fetal maturation. Studies on placental barrier function have produced discordant results $(9,10)$. The primary human trophoblast cells of full-term placentae have been shown to be refractory to historic strains of Zika virus from Uganda (MR766) and Cambodia (FSS13025). However, a contemporary strain of Zika virus from Puerto Rico (PRVABC59) was able to infect human placental macrophages and mature primary human trophoblast cells (9). In addition, primary human trophoblast cells in a nonZika virus-endemic population were permissive to a strain of Zika virus from Colombia (FLR) (10).

Taken together, uncertainty about the mode of transmission and discrepancies in epidemiologic study findings make it imperative to aggregate data to enable comparisons of the risk for transmission as a function of exposure during gestation. More accurate risk estimates should soon be possible thanks to efforts (meta-analyses of individual participant data of existing cohorts) of the international community, which should enable harmonized follow-up and evaluation of developmental outcomes for children exposed to Zika virus.

\section{Acknowledgment}

We thank the nurses and Centre de Liaison sur l'Intervention et la Prévention Psychosociale members for the realization and interpretation of the CDAS.

Dr. Besnard is a pediatrician/neonatologist at the Centre Hospitalier de Polynésie Française. She is involved in prenatal diagnosis and in the description of fetal and child consequences of arboviruses circulating in the Pacific Region.

\section{References}

1. Moore CA, Staples JE, Dobyns WB, Pessoa A, Ventura CV, Fonseca EB, et al. Characterizing the pattern of anomalies in congenital Zika syndrome for pediatric clinicians. JAMA Pediatr. 2017;171:288-95. http://dx.doi.org/10.1001/ jamapediatrics.2016.3982

2. Rasmussen SA, Jamieson DJ, Honein MA, Petersen LR. Zika virus and birth defects - reviewing the evidence for causality. N Engl J Med. 2016;374:1981-7. http://dx.doi.org/10.1056/NEJMsr1604338

3. Moura da Silva AA, Ganz JS, Sousa PD, Doriqui MJ, Ribeiro MR, Branco MD, et al. Early growth and neurologic outcomes of infants with probable congenital Zika virus syndrome. Emerg Infect Dis. 2016;22:1953-6. http://dx.doi.org/10.3201/eid2211.160956

4. van der Linden V, Pessoa A, Dobyns W, Barkovich AJ, Júnior HV, Filho EL, et al. Description of 13 infants born during October 2015-January 2016 with congenital Zika virus infection without microcephaly at birth - Brazil. MMWR Morb Mortal Wkly Rep. 2016;65:1343-8. http://dx.doi.org/10.15585/mmwr.mm6547e2

5. Aubry M, Teissier A, Huart M, Merceron S, Vanhomwegen J, Roche C, et al. Zika virus seroprevalence, French Polynesia, 2014-2015. Emerg Infect Dis. 2017;23:669-72. http://dx.doi.org/ 10.3201/eid2304.161549

6. Besnard M, Lastère S, Teissier A, Cao-Lormeau V, Musso D. Evidence of perinatal transmission of Zika virus, French Polynesia, December 2013 and February 2014. Euro Surveill. 2014;19:20751. http://dx.doi.org/10.2807/1560-7917.ES2014.19.13.20751

7. Paz-Bailey G, Rosenberg ES, Doyle K, Munoz-Jordan J, Santiago GA, Klein L, et al. Persistence of Zika virus in body fluids. Preliminary report. N Engl J Med. 2016 Feb 14 [Epub ahead of print]. 
8. Soares de Souza A, Moraes Dias C, Braga FD, Terzian AC, Estofolete CF, Oliani AH, et al. Fetal infection by Zika virus in the third trimester. Report of 2 cases. Clin Infect Dis. 2016;63:1622-5. http://dx.doi.org/10.1093/cid/ciw613

9. Quicke KM, Bowen JR, Johnson EL, McDonald CE, Ma H, O'Neal JT, et al. Zika virus infects human placental macrophages. Cell Host Microbe. 2016;20:83-90. http://dx.doi.org/10.1016/ j.chom.2016.05.015

10. Aagaard KM, Lahon A, Suter MA, Arya RP, Seferovic MD, Vogt MB, et al. Primary human placental trophoblasts are permissive for Zika virus (ZIKV) replication. Sci Rep. 2017;7:41389. http://dx.doi.org/10.1038/srep41389

Address for correspondence: Marianne Besnard, Centre Hospitalier de Polynésie Française, BP 1640 Papeete Tahiti Papeete 98713, French Polynesia; email: mbesnard@nohao.net

\section{California Serogroup Virus Infection Associated with Encephalitis and Cognitive Decline, Canada, 2015}

\section{Duncan Webster, Kristina Dimitrova, Kimberly Holloway, Kai Makowski, David Safronetz, Michael A. Drebot}

\author{
Author affiliations: Dalhousie University, Saint John, \\ New Brunswick, Canada (D. Webster); Public Health Agency of \\ Canada, Winnipeg, Manitoba, Canada (K. Dimitrova, K. Holloway, \\ K. Makowski, D. Safronetz, M.A. Drebot)
}

DOI: https://doi.org/10.3201/eid2308.170239

California serogroup (CSG) viruses, such as Jamestown Canyon and snowshoe hare viruses, are mosquitoborne pathogens that cause febrile illness and neurologic disease. Human exposures have been described across Canada, but infections are likely underdiagnosed. We describe a case of neuroinvasive illness in a New Brunswick, Canada, patient infected with a CSG virus.

$\mathrm{C}$ alifornia serogroup (CSG) viruses (family Bunyaviridae, genus Orthobunyavirus) (1) include the mosquitoborne pathogens Jamestown Canyon virus (JCV), snowshoe hare virus (SSHV), and La Crosse virus. Competent vectors include non-Culex mosquitoes (e.g., Aedes, Culiseta, and Anopheles species), all of which circulate in New Brunswick, Canada $(2,3)$. The major reservoir and vertebrate amplifier of JCV is believed to be the white-tailed deer (4). Squirrels, chipmunks, and hares serve as vertebrate reservoirs for SSHV (5). CSG virus infection is generally asymptomatic; however, after an incubation period of 3-7 days, a febrile illness may develop, and central nervous system involvement may lead to encephalitis or meningoencephalitis (6). No targeted therapies exist; treatment is supportive.

We describe a previously independent 73-year-old man, living on Grand Manan Island, off the Fundy Coast of southern New Brunswick, with a febrile illness that began July 23, 2015. The man was hospitalized, and the next day he exhibited abnormal behaviors (purposeless movements and incoherent speech) and became increasingly confused. The confusion and fever continued to worsen, and headache and neck pain developed. On July 28, he was treated with ceftriaxone and transferred to a tertiary-care hospital (Saint John Regional Hospital, Saint John, New Brunswick), where ampicillin and acyclovir were administered. Cerebral spinal fluid values were as follows: leukocyte count, $1 \times 10^{6} \mathrm{cells} / \mathrm{L}$ (reference range $0-5 \times 10^{6}$ cells $/ \mathrm{L}$ ); glucose, $3.5 \mathrm{mmol} / \mathrm{L}$ (reference range 2.2-3.9 $\mathrm{mmol} / \mathrm{L}$ ); and protein concentration, $0.58 \mathrm{~g} / \mathrm{L}$ (reference range $0.15-0.45 \mathrm{~g} / \mathrm{L}$ ). On July 30 , an infectious diseases specialist diagnosed the patient with viral encephalitis, most likely secondary to herpes simplex virus infection; ceftriaxone and ampicillin were discontinued. At a neurology consultation on July 31, the patient was still febrile and confused; brain magnetic resonance imaging revealed no acute pathology.

On August 4, additional information revealed that the patient went on frequent excursions into the woods of Grand Manan Island and had exposures to feral cats. Doxycycline was initiated, and serologic tests were conducted for Bartonella, Borrelia, Coxiella, and Anaplasma species and for Powassan virus, JCV, and SSHV; tests were also conducted to rule out paraneoplastic process and autoimmune causes. By August 12, the patient was afebrile but remained confused. On August 18, PCR was negative for herpes simplex virus in CSF, and an electroencephalograph revealed no periodic lateralizing epileptiform discharges; acyclovir was discontinued. Initial serologic test results were negative, and the patient showed no autoimmune or paraneoplastic markers. During a geriatric assessment, the patient showed persistent delirium, scoring $13 / 30$ on a mini-mental state examination.

On August 21, we received the patient's initial CSG serology results and collected follow-up serum samples for standard serologic testing by IgM capture ELISA and plaque-reduction neutralization testing (PRNT) $(7,8)$. The acute-phase serum sample was IgM-negative but positive for CSG virus-specific neutralizing antibodies by PRNT (Table). Serial convalescent-phase serum specimens demonstrated IgM seroconversion several weeks after symptom onset and $\mathrm{a} \geq 4$-fold rise in PRNT titers for JCV and SSHV, indicating a diagnostic rise. Because serum neutralization 